\title{
Spectrophotometric analysis of phosphate concentration in agricultural soil samples and water samples using molybdenum blue method
}

\section{Funmilayo Enitan Adelowo and Solomon Oluwole Oladeji}

Department of Pure and Applied Chemistry. Ladoke Akintola University of Technology. P. M. B. 4000. Ogbomoso. Nigeria. Email: oladeji_oluwole@yahoo.com, feadelowo@lautech.edu.ng.

\begin{abstract}
Phosphorus has a strong affinity for soil thereby increasing the rate of dissolved phosphorus that will be transported in runoff. The most important contributing factor for increasing in phosphates levels are natural and human factors such as dumping of refuse from nearby areas, use of fertilizers and human excretes. The phosphate levels in the soil and water samples (expressed in part per million) was analyzed by molybdenum blue phosphorus method using a simple analytical and UV-visible spectrophotometric method and the phosphates level was measured at $740 \mathrm{~nm}$. The calibration curve was formed using concentrations of $0.5-3.0 \mathrm{mg} / \mathrm{L}$. The samples analyzed showed high levels of phosphates which could be due to domestic, natural and agricultural factors.
\end{abstract}

Keywords: Phosphates levels; Molybdenum blue phosphorus method; Calibration curve; Pollutants; UV-visible spectrophotometer.
Received

June 30, 2016

Accepted

December 22, 2016

Released

December 31, 2016

Open Acess Full Text Article

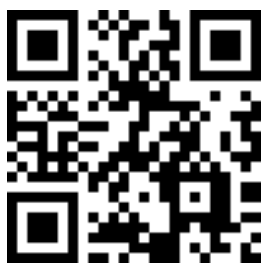

$$
\begin{aligned}
& \text { ORCID } \\
& \text { (1) 0000-0001-7748-6131 } \\
& \text { Funmilayo Enitan } \\
& \text { Adelowo } \\
& \text { 0000-0002-8534-7331 } \\
& \text { Solomon } \quad \text { Oluwole } \\
& \text { Oladeji }
\end{aligned}
$$

\section{Introduction}

The chemistry of soil indicates that it contains several chemical components ranging from organic to inorganic compounds. Scientifically, it is defined as the outermost or weathered superficial layer of the earth's crust. They are consists mainly of decomposed parent rock material (organic matter), mineral (inorganic) matter, water, air and organisms (Weier,
1973). Soil is a complex system which includes Soil and water is one of the major constituents of the earth. Geographically, the earth crust contains $70 \%$ of water (hydrosphere) (Oladeji et al., 2016). From recent researches, scientists discovered that soil and water contains many metals, chemical constituents or compounds. Some of these include phosphates, nitrates and sulphates amongst others. From soil the 
plant absorbs water and solutes necessary for its continued well-being.

Phosphorus is an important nutrient that occurs widely in the environment. It is the key elements necessary for the growth of plants and animals and also, assists in metabolism. In the earth crust, it is the eleventh most abundant element on the surface of the earth and is most commonly found as phosphate (Chaube and Gupta, 1983). Eutrophication of surface water is caused by increase level of phosphate in water and this increases the growth of algae thereby reduce the light intensity and level of dissolved oxygen in the water. Researches and recent report indicates the high utilization of phosphates in detergents, fertilizers, sugar industries amongst others, thus the determination of phosphorus is important to water analyst and limnologist (Kharat and Pagar, 2009). Due to these reports, various phosphate determination procedures titrimetry, complexogravimetry, colorimetry, atomic absorption spectroscopy, flow injection analysis, and spectrophotometry methods (Verma, 1988; Bøtker et al., 1994). In the attempt to quantitate the phosphate level, spectrophotometric methods have been preferred because it involves no extraction, sosphicated instruments and easily accessible. The commonest spectrophotometric includes molybdovanadate and ammonium molybdate methods (Vogel, 1999). In ammonium molybdate spectrophotometric method, reducing agents such as tin(II) chloride, ascorbic acid and 1-amino-2naphthol-4-sulfonic acid are often preferred. It also involves the formation of molybdophosphoric acid from ortho phosphate and an excess of molybdate in acidic solution followed by reduction to give molybdenum blue. The concentrations or phosphate levels in the sample is proportional to the intensity of colour produced and the absorbance is measured spectrophotometrically at a certain wavelength. In the attempt to reduce the health and environmental hazards by phosphate contamination, spectrophotometrically analysis of phosphate in soil and water sample is inevitable.

\section{Materials and methods}

\section{Chemicals and reagents}

All the chemicals and reagents used were analytical reagent grade unless otherwise stated and the solutions were prepared in double distilled water.

\section{Instruments}

The absorbance were determined using ultraviolet visible spectrophotometer, model WPAS $104 \mathrm{UK}$ with $1 \mathrm{~cm}$ matched quartz cells.

\section{Preparation of standard solutions (stock solution)}

About $0.717 \mathrm{~g}$ of potassium dihydrogenphosphate $\left(\mathrm{KH}_{2} \mathrm{PO}_{4}\right)$ was accurately weighed and dissolved in double distilled water and the volume was made $500 \mathrm{~mL}$ in a volumetric flask. The working phosphate solutions of different concentrations were prepared by serial dilution of the stock solution (Oladeji et al., 2016).

Preparation of working solution of ammonium molybdate

About $1.7081 \mathrm{~g}$ of ammonium molybdate was accurately weighed and dissolved in $100 \mathrm{~mL}$ of warm water; a milky colouration was observed, cooled and transferred into $250 \mathrm{~mL}$ volumetric flask.

\section{Preparation of dilute hydrochloric acid}

A measured amount of concentrated hydrochloric acid solution was diluted and made up to mark in a $100 \mathrm{~mL}$ of volumetric flask.

\section{Preparation of dilute trioxonitrate $(\mathrm{V})$ acid}

A measured amount of $50 \mathrm{~mL}$ of concentrated trioxonitrate (V) acid solution was diluted and made up to mark in a 100 $\mathrm{mL}$ of volumetric flask. 
Preparation of hydrazine hydrate

About $0.125 \mathrm{~g}$ of hydrazine sulphate was accurately weighed and dissolved with double distilled water in a clean beaker in a $100 \mathrm{~mL}$ standard flask and made up to calibrated mark.

\section{Soil sample collection and preparation. \\ Soil sample was taken from} Goddex and Linkway Farms in Ogbomoso. The sample was dried for 10 days, sieved and stored for further analysis.

\section{preparation \\ Water sample collection and}

About $50 \mathrm{~mL}$ of water samples were collected in March, 2016 from three major rivers (Arowomole, Odoje and Alapata Rivers) located in the Southern part of Ogbomoso, Nigeria. The water samples were filtered using filter paper No. 42. The filtered samples was then stored in clean sample bottle.

\section{Soil sample analysis for}

About $2 \mathrm{~g}$ of the soil sample was accurately weighed and placed in a $250 \mathrm{~mL}$ conical flask, $60 \mathrm{~mL}$ of $\mathrm{HCl}$ and $\mathrm{HNO}_{3}$ (ratio of 3 to 1 ) was added and shaken in a mechanical shaker for $30 \mathrm{~min}$. The digestion was done for $6 \mathrm{~h}: 30 \mathrm{~min}$. This was then filtered using filter paper Whatmann No. 41. About $15 \mathrm{~mL}$ of the filtered digested sample was taken, $3 \mathrm{~mL}$ of ammonium molybdate, $2 \mathrm{~mL}$ of hydrazine sulphate was added and kept in a water bath for $30 \mathrm{~min}$. The blue colour observed was measured (Amponsah et al., 2014).

\section{phosphates \\ Water sample analysis for \\ About $15 \mathrm{~mL}$ of the filtered water} sample was accurately measured, $3 \mathrm{~mL}$ of ammonium molybdate, $2 \mathrm{~mL}$ of hydrazine sulphate was added and kept in a water bath for $30 \mathrm{~min}$. The blue colour observed was measured (Amponsah et al., 2014).

\section{Results and discussion}

\section{absorbance \\ Determination of maximum}

The absorption spectral data of the potassium dihydrogenphosphate used as standard against the reagent blank (water) exhibit the wave length of maximum absorbance around $740 \mathrm{~nm}$.

\section{Calibration curve for the standard $\left(\mathrm{KH}_{2} \mathrm{PO}_{4}\right)$}

The molybdenum blue method is based on the formation of phosphomolybdate. At effective analytical conditions, the amount of phosphates is proportional to the intensity of colour (blue) in the stock solution $\left(\mathrm{KH}_{2} \mathrm{PO}_{4}\right)$. The calibration curve of the absorbance from the UV-visible spectrophotometer of concentrations $0.5-3.0 \mathrm{mg} / \mathrm{L}$, respectively, is given below in Figure 1 from Table 1.

\section{Phosphate analysis in soil and water samples}

The analytical results of phosphate analysis in soil and water samples are shown in Table 2. The phosphates concentration in soil and water was obtained by interpolating the calibration curve in Fig 1. The highest concentration of phosphate was obtained from Goddex Farms $\left(\mathrm{S}_{\mathrm{F} 1}\right)$ with a concentration of $2.80 \mathrm{mg} / \mathrm{L}$, the lowest being Odoje River with concentration $\left(\mathrm{W}_{2}\right)$ of $1.480 \mathrm{mg} / \mathrm{L}$. The uses of fertilizers, detergents, fungicides and even paints have been discovered to be the major pollutants in Ogbomoso, Nigeria. There is no healthbased guideline proposed for phosphate consumption, thou, medically high intake of phosphate can cause health problems like cancer, ulcers, kidney problems, brain damage and gastrointestinal effects. The use of fertilizers, herbicides, fungicides in farm help improve the quality of farm produce. The environmental protection agency has a recommended limit for phosphates levels in soil and water bodies. For streams and rivers the Environmental Protection Agency recommended limit is 
$0.1 \mathrm{mg} / \mathrm{L}$. The following recommendations are also given for phosphate consumptions: total phosphorus; no more than $0.1 \mathrm{mg} / \mathrm{L}$ for streams which do not empty into reservoir, $\quad 0.05 \mathrm{mg} / \mathrm{L}$ for streams discharging into reservoirs and $0.025 \mathrm{mg} / \mathrm{L}$ for reservoirs (Oladeji et al., 2016). It is recommended that health authorities be notified of sources of drinking. Man made sources of phosphate include human sewage, agricultural run-off from crops, sewage from animal feedlots, pulp and paper industry, vegetable and fruit processing, chemical and fertilizer manufacturing, and detergents (McCoy, 2011).

Table 1. The absorbance, $A_{T}$ obtained from different concentration (mg/L) of potassium dihydrogenphosphate.

\begin{tabular}{|c|c|c|}
\hline & $\mathbf{C}_{\mathbf{T}}$ & $\mathbf{A}_{\mathbf{T}}$ \\
\hline 1. & 0.00 & 0.000 \\
\hline 2. & 0.50 & 0.230 \\
\hline 3. & 1.00 & 0.386 \\
\hline 4. & 1.50 & 0.580 \\
\hline 5. & 2.00 & 0.759 \\
\hline 6. & 2.50 & 0.831 \\
\hline 7. & 3.00 & 1.172 \\
\hline
\end{tabular}

Where $\mathrm{CT}=$ concentration $(\mathrm{mg} / \mathrm{L}) ; \mathrm{A}_{\mathrm{T}}=$ absorbance .

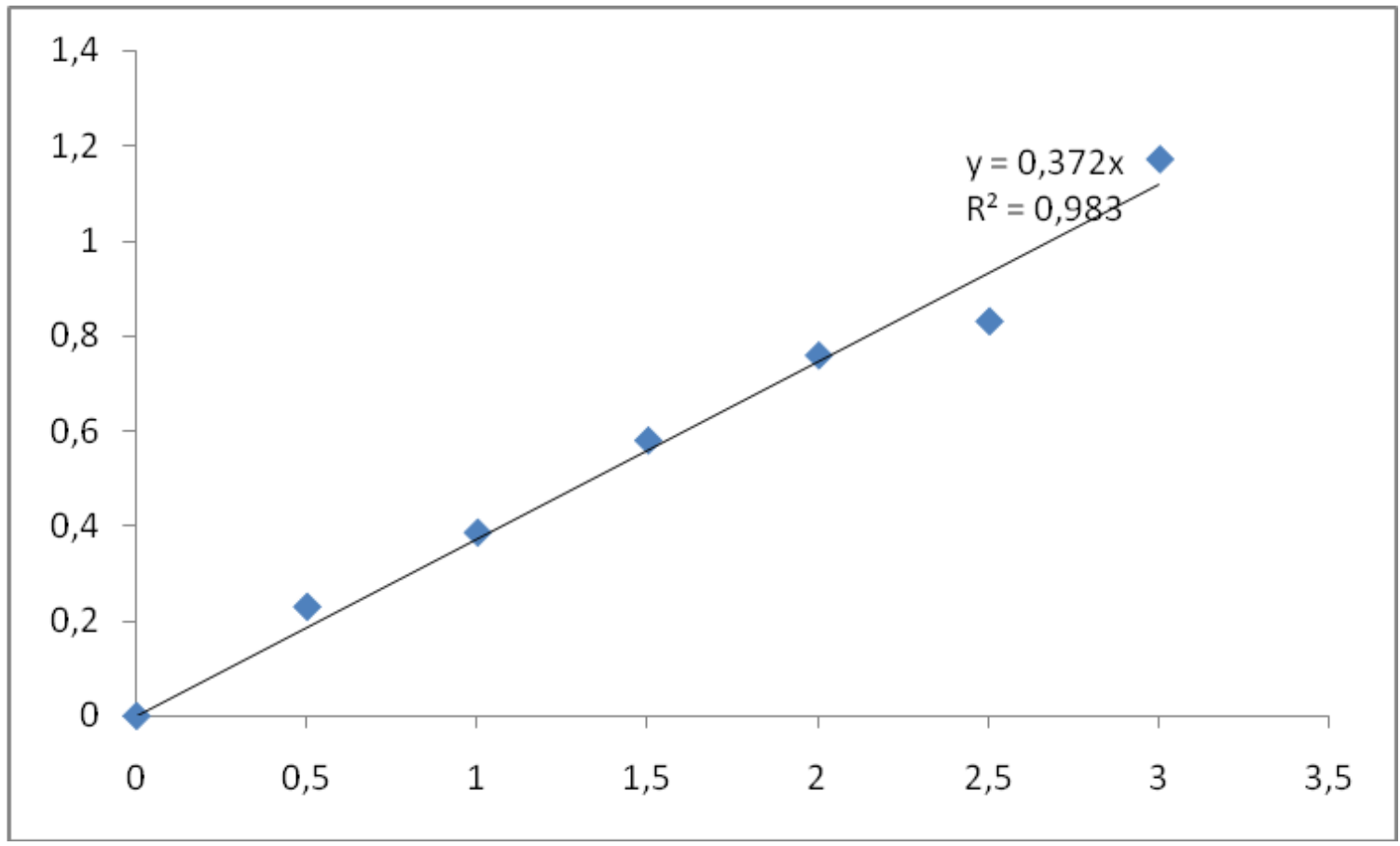

Figure 1. The calibration curve for the standard solution $\left(\mathrm{KH}_{2} \mathrm{PO}_{4}\right)$ 
The highest concentration of phosphates at Goddex Farms $\left(\mathrm{S}_{\mathrm{F} 1}\right)$ could be attributed to the mixed farming activities in the farm. There was an indication that the use of manure (cow dung) and inorganic fertilizers (phosphate fertilizers) was the usual practice in this farm. The use of fertilizers in agriculture is paramount when compare with herbicides, fungicides and nematocides uses. The high level of phosphates in soil samples taken from maize fields (SF1 and SF2) could be due to the use of phosphates fertilizers and have higher level when compared to soil samples taken from lands sprayed with phosphates fungicides. In water samples, the high level of phosphates was recorded in Arowomole River $\left(\mathrm{W}_{1}\right)$. This could be due to the industrial, human and farming activities in the community. The dumping of refuse, sewage, human waste could also be a major factor. The laundry activities, car-washing, block industry and also farming activities are also major contributing factors (McCoy, 2011). Also, in Alapata River, $W_{3}$, residents close to this water source uses phosphate containing detergents.

Table 2. The absorbance of the water samples and their corresponding concentrations obtained from the calibration curve.

\begin{tabular}{|c|c|}
\hline Sampling Area & $\mathbf{C}_{\mathbf{T}}$ \\
\hline W1 & 1.650 \\
\hline W2 & 1.480 \\
\hline W3 & 1.510 \\
\hline SF1 & 2.800 \\
\hline SF2 & 2.650 \\
\hline SP1 & 1.970 \\
\hline SP2 & 2.050 \\
\hline
\end{tabular}

Where $\mathrm{C}_{\mathrm{T}}$ concentration (mg/L)

The increased eutrophication have some negative environmental and human impacts such as reduced aesthetic and recreational value of lakes, river and stream as well as the seasonal depletion of the water dissolved oxygen content, and this could leads to destruction and even death of fish as well as other ecosystem disruptions (Smith et al., 1999).

The soil and water samples showed that all the samples exceeded the recommended phosphate concentration level. The high concentration of phosphates is due to natural and human factors such as erosion, leaching and weathering and also, runoff from nearby farm and nearby residential areas.

\section{Conclusion}

The spectrophotometric analysis using ammonium molybdate as reductants proved effective analytical for the determination of phosphate. It involves the reduction of phosphomolybdate by potassium dihydrogenphosphate. The phosphate concentration in the samples was measured at $740 \mathrm{~nm}$. The phosphates levels are high in all the samples when compared to the Environmental Protection Agency. This could be due to natural such as erosion and weathering, agricultural and also human activities. In the attempt to prevent the effects of high phosphates, the use of phosphate containing materials such be 
reduce and the people in these area should be enlighten on the health effects on these phosphate levels can cause.

\section{Acknowledgements}

The authors are grateful to the Laboratory Technologists of the Department of Pure and Applied Chemistry, LAUTECH, Ogbomoso, Nigeria, for the assistance and encouragement during the course of the research.

\section{Conflicts of interest}

Authors declare that they have no conflict of interests.

\section{References}

Amponsah, D.; Etsey, G.; Nagai, H. Determination of amount of phosphate and sulphate in soil samples from university of Cape Coast Farm. International J. Sci. Tech. Res., v. 3, no. 7, p. 211-215, 2014. Available from: <http://www.ijstr.org/final-print/july2014/

Determination-Of-Amount-Of-Phosphate-AndSulphate-In-Soil-Samples-From-University-OfCape-Coast-Farm.pdf $>$. Accessed on: Apr. 23, 2016.

Bøtker, H. E.; Kimose, H. H.; Helligsø, P.; Nielsen, T. T. Analytical evaluation of high energy phosphate determination by high performance liquid chromatography in myocardial tissue. Journal of Molecular and Cellular Cardiology, v. 26, no. 1, p. 41-48, 1994. http://dx.doi.org/10.1006/jmcc.1994.1006
Chaube, M. A.; Gupta, V. K. Spectrophotometric determination of phosphate in polluted waters by solvent extraction of molybdenum blue. Analyst., v. 108, p. 1141-1144, 1983. http://dx.doi.org/10.1039/AN9830801141

Kharat S. J.; Pagar, S. D. Determination of phosphate in water samples of Nashik District Rivers by UV-visible spectroscopy. E-Journal Chem., v. 6, Suppl. 1, p. S515-S521, 2009. http://dx.doi.org/10.1155/2009/913609

McCoy, M. Goodbye phosphates. Chemical and Engineering News, v. 89, no. 4, p. 12-17, 2011. Available from: <https://pubs.acs.org/ cen/coverstory/89/8904cover.html $>$. Accessed on: Jun. 23, 2016.

Oladeji, S. O.; Adelowo, F. E.; Odelade, K. A. Evaluation of phosphate level in water samples (Ogbomoso Rivers) using UV-visible spectrophotometric method. Int. J. Sci. Res. Env. Sci., v. 4, no. 4, p. 102-108, 2016. http://dx.doi.org/10.12983/ijsres-2016-p01020108

Smith, V.; Tilman, G.; Nekola, J. Eutrophication: impacts of excess nutrient in freshwater, marine and terrestrial ecosystems. Environ. Pol., v. 100, no. 1/3, p. 179-196, $1999 . \quad$ http://dx.doi.org/10.1016/S02697491(99)00091-3

Verma, N. C. System of technical control for cane sugar factories in India. The Sugar Technologists Association of India, 1988.

Vogel, A. A text book of quantitative chemical analysis. 5. ed. London: Longmans, 1991.

Weier T. E.; Stocking C. R.; Barbour, M. G. An introduction to plant Biology. 5. ed. Davis, California: University of California, 1973. 
License information: This is an open-access article distributed under the terms of the Creative Commons Attribution License, which permits unrestricted use, distribution, and reproduction in any medium, provided the original work is properly cited.

Braz. J. Biol. Sci., 2016, v. 3, no. 6, p. 407-412. 